\title{
Screening of novel 2-4methylphenylimino-3-carboxamide substituted thiophene compound for peripheral analgesic activity
}

\author{
Nishitha Ganugapeta ${ }^{1 *}$, Sai Sravan Kumar Reddythala ${ }^{2}$
}

${ }^{1}$ Department of Pharmacology, ${ }^{2}$ Department of Community Medicine, PESIMSR, Kuppam, Andhra Pradesh, India

Received: 01 February 2021

Revised: 18 February 2021

Accepted: 19 February 2021

\section{*Correspondence:}

Dr. Nishitha Ganugapeta,

Email: drnishithasai@gmail.com

Copyright: (C) the author(s), publisher and licensee Medip Academy. This is an open-access article distributed under the terms of the Creative Commons Attribution Non-Commercial License, which permits unrestricted non-commercial use, distribution, and reproduction in any medium, provided the original work is properly cited.

\begin{abstract}
Background: Pain is an unpleasant sensation that can range from mild, localized discomfort to agony. The mechanism of pain perception involves dedicated subsets of peripheral and central neurons. For management of pain, currently, available treatment regimens are opioid analgesics and NSAIDs which are easily available over the counter drugs. Long term use of analgesics can lead to significant impact on human renal system, cardiovascular system and analgesic abuse etc. So, there is a need for novel, safe and cost effective analgesic compound. Hence a study on 2-4methylphenylimino3-carboxamide substituted thiophene compound, a novel thiophene compound has been carried out in different experimental animal models.

Methods: Two methods were used to evaluate the peripheral analgesic activity of 2-4methylphenylimino-3carboxamide substituted thiophene compound. First method was Acetic acid induced writhing and compared to standard drug aspirin. Second method was late phase of formalin induced paw licking in mice and compared to a standard drug, aspirin.

Results: With Acetic acid induced writhing, 40mg/kg dose of 2-4methylphenylimino-3-carboxamide substituted thiophene compound has shown maximum Pain Inhibition Percentage (PIP) of $78 \%$ compared to $91 \%$ by Aspirin. Whereas with late phase of Formalin test, $40 \mathrm{mg} / \mathrm{kg}$ dose of 2-4methylphenylimino-3-carboxamide substituted thiophene compound has shown maximum PIP of $58 \%$ in late phase compared to $86 \%$ by aspirin. The results were statistically significant with $\mathrm{p}<0.05$.

Conclusions: It can be concluded that 2-4methylphenylimino-3-carboxamide substituted thiophene compound found to have moderate peripheral analgesic activity as evident in acetic acid induced writhing and late phase of formalin tests.
\end{abstract}

Keywords: Analgesic, Acetic acid induced writhing, Formalin test, Thiophene, 2-4 Methylphenylimino-3-carboxamide substituted thiophene compound

\section{INTRODUCTION}

Despite an enhanced recognition of the molecular mechanisms of nociception, existing analgesic drugs continue to remain restricted in terms of efficacy since several mechanisms act in tandem to produce pain. Drugs acting either on the opioid receptor system or inflammatory cascade have been the only successful molecules over the past few decades. At this time, the marketed analgesic drugs are at best modestly effective and many of them are known to cause unacceptable side effects or have been linked to longterm safety issues. ${ }^{1}$ Among the various marked oral analgesic drugs ibuprofen has emerged as the safest and is available as an OTC product in many countries. ${ }^{2}$ No one likes the pain but it is one of the most important defensive mechanisms in our body, which provide us signal about the abnormality. Depending upon the severity and intensity of threshold, pain has classified into two main classes either acute or 
chronic. When pain occurs in quick succession and disappears after few hours or day with or without medication then it is acute type and one the other hand if it develops after long time and goes slowly or incompletely than it is a chronic type. From the point or origin to the point of receiving, sensation of pain, involve central as well as peripheral nervous system. Alleviation of pain depends on several factors like its type, its origin point, and causes behind that pain. Neurogenic pain may be arise due to anxiety, depression, mania, epilepsy, seizer, phobia and many more, so their treatment need application of neurotherapeutic agents which act on serotonin/nor epinephrine reuptake inhibitor while the normal pain such as, body ach, arthritic pain, inflammatory pain, traumatic pain need normal analgesic medication like non-steroidal anti-inflammatory agents. ${ }^{3}$ The chronic pain state is characterized by changes in somatosensory processing, affect, and motivation. ${ }^{4}$ Human imaging studies suggest that alterations in mesolimbic circuitry of the brain accompany establishment of this state. ${ }^{5}$ The nucleus accumbens (NAc) is a key hub in themesolimbic circuitry, and the release of dopamine (DA) in the NAc by neurons in the ventral tegmental area (VTA) modulates its functional connectivity with other regions implicated in chronic pain, such as the prefrontal cortex, amygdala, and hippocampus. ${ }^{6,7}$

In today's competitive world, people are always in race to surge ahead of each other. In doing so, we compromise with our health and suffer with pain viz. headache, back pain etc. Many of these pains are commonly due to our lifestyle and occupational hazards. In order to relieve ourselves from the pain, we rely on pain killer, but there is a great need for the development of better drugs for the alleviation and control of both acute (immediate) and chronic (long-term, pathological) pain. ${ }^{8}$ Long term use of available analgesics causes disturbances in the body system. Opioids cause multiple adverse effects involving respiratory system, central nervous system, gastrointestinal system such as sedation, mental clouding, blurring of vision, respiratory depression, constipation and urinary retention. NSAIDs cause adverse effects involving several systems of the body such as gastrointestinal tract, kidneys, central nervous system, cardiovascular system, blood and skin. A search for new, safe \& cost-effective analgesic continues. A study on 2-4methylphenylimino-3carboxamide substituted thiophene compound has been carried out. The parent compound has been studied and shows predominant analgesic activity at 15 to $30 \mathrm{mg} / \mathrm{kg} .{ }^{9}$

\section{METHODS}

Currently in this study, peripheral analgesic activity of test compound was evaluated using two experimental animal models. First method was Acetic acid induced writhing in mice and second method was Late phase of formalin induced paw licking in mice. The study was conducted in the Animal house affiliated to the People's Education Society Institute of Medical Sciences and Research, Kuppam, Chittoor district, Andhra Pradesh after obtaining approval from the Institutional Animal Ethics Committee (No: PES IMSR / Pharma / IAEC / 12 / 2012-13). All the animals were handled with gentle care as per the CPCSEA guidelines.

\section{Details of experimental animals used}

The current study was carried out in healthy male Swiss albino mice (Mus musculus) weighing between 20 to $25 \mathrm{~g}$ as they are the most widely used strain for assay of analgesics 15 . Female mice were excluded to avoid the effect of estrous cycle. Also, the diseased mice and male mice weighing $<20 \mathrm{~g}$ and $>25 \mathrm{~g}$ were also excluded. All the mice were in propylene cages in 12:12 hours light: dark cycle, under standard laboratory conditions and water was provided ad libitum. All the mice were kept in fasting state 12 hours prior to the conduction of experiment.

\section{Test compound}

2-4 methyl phenylimino-3-carboxamide substituted thiophene compound. Thiophene is a five-membered heterocyclic compound having Sulphur as the heteroatom. Over the past few years, research groups have conducted a comprehensive program me towards the synthesis of thiophene and their fused derivatives which have reported to possess wide range of activity. It has been reported that the parent compound, Thiophene and its derivatives possess analgesic, anti-inflammatory, local anesthetic, antimicrobial and antifungal activities. ${ }^{10-14}$ In view of these findings, another novel synthesized derivative of thiophene namely 2-(4-Methylphenylimino)-N-(2Chlorophenyl)-5-Isopropyl-4-Methyl Thiophene-3Carboxamide substituted Thiophene was undertaken in the present study to evaluate the analgesic activity. It was synthesized in the P.E.S college of pharmacy, Bangalore and obtained by their kind courtesy.

\section{Acetic acid induced writhing in mice}

This experiment has been performed to verify the peripheral analgesic activity of 2-4methylphenylimino-3carboxamide substituted thiophene compound. In this chemical method, acetic acid was injected as irritant into peritoneum to induce pain of peripheral origin in mice. ${ }^{16,17}$ If the test compound has analgesic activity, then it can be inferred from decrease in frequency of writhings. Sigmund et al first described manifestations of abdominal writhings in mice as an arching of back, extension of hind limbs and contraction of abdominal musculature. ${ }^{18}$

The formalin test may allow dissociation between inflammatory and non-inflammatory pain, a rough classification of analgesics according to their site and their mechanism of action.

\section{Animals}

A total of 30 male Swiss albino mice were considered for this study. 


\section{Drugs and reagents}

The test compound 2-4methylphenylimino-3-carboxamide substituted thiophene compound cannot be dissolved in water hence, drug suspending agent $10 \%$ Tween- 80 or Polysorbate-80 (Merck Specialties private limited, Mumbai), was used. Acetic acid $0.6 \%$ was used. The standard drug utilized in this experiment was Aspirin, and test compound 2-4methylphenylimino-3-carboxamide substituted thiophene compound, both the drugs were administered orally using gavage.
Five groups of mice were created, and all the mice were selected randomly. Each group contains six mice. Group I received $0.5 \mathrm{ml}$ of tween- 80 per oral which was considered as control group. Group II received Aspirin which was considered as standard group. Groups III, IV and V received the test drug 2-4 methylphenylimino-3carboxamide substituted thiophene compound per orally at $10 \mathrm{mg} / \mathrm{kg}, 20 \mathrm{mg} / \mathrm{kg}, 40 \mathrm{mg} / \mathrm{kg}$ respectively and all these three groups were considered as test groups. All the grouping details were mentioned below in Table 1.

Table 1: Classification of mice into the groups in Acetic acid induced writhing in mice.

\begin{tabular}{|lll|}
\hline Group & Drug & Dose \\
\hline I & Control (10\% tween-80) & $0.5 \mathrm{ml} \mathrm{PO}$ \\
\hline II & Aspirin & $100 \mathrm{mg} / \mathrm{kg} / \mathrm{PO} / 0.5 \mathrm{ml}$ \\
\hline III & 2-4methylphenylimino-3-carboxamide substituted thiophene compound & $10 \mathrm{mg} / \mathrm{kg} / \mathrm{PO} / 0.5 \mathrm{ml}$ \\
\hline IV & 2-4methylphenylimino-3-carboxamide substituted thiophene compound & $20 \mathrm{mg} / \mathrm{kg} / \mathrm{PO} / 0.5 \mathrm{ml}$ \\
\hline V & 2-4methylphenylimino-3-carboxamide substituted thiophene compound & $40 \mathrm{mg} / \mathrm{kg} / \mathrm{PO} / 0.5 \mathrm{ml}$ \\
\hline
\end{tabular}

Mice were administered orally with respective drug. After 1 hour, $0.1 \mathrm{ml}$ of $0.6 \%$ acetic acid is injected intraperitoneally. Total number of writhes are recorded for a period of 20 minutes. For scoring purpose, writhe is indicated by characteristic abdominal stretching with simultaneous stretching of at least one hind limb. ${ }^{19}$ Pain inhibition percentage (PIP) of the test group is calculated from the mean writhing count of control group. ${ }^{20}$

\section{Formalin induced paw licking in mice - only late phase}

Late phase of formalin induced paw licking method has been evaluated for peripheral analgesic activity of 2-4methyl-phenylimino-3-carboxamide substituted thiophene compound. 30 male mice $(20-25 \mathrm{~g})$ divided into 5 groups consisting of 6 animals in each group were randomly grouped as follows.

\section{Animals}

A total of 30 male Swiss albino mice were included for this study.

\section{Drugs and reagents}

Total $10 \%$ Tween- 80 or Polysorbate- 80 was used as a drug suspending agent, whereas Aspirin was used as a standard drug and 2-4methylphenylimino-3-carboxamide substituted thiophene compound as test compound. All drugs were administered orally using gavage. The procedure was done as per the standard method suggested by Murray et al and Hunskaar and Hole. ${ }^{21-23}$ Five groups of mice were created, and all the mice were selected randomly. Each group contains six mice. Group I received $0.5 \mathrm{ml}$ of tween-80 per oral which was considered as control group. Group II received aspirin per orally at the dose of $100 \mathrm{mg} / \mathrm{kg} / \mathrm{PO} / 0.5 \mathrm{ml}$ which was considered as standard group. ${ }^{24}$ Groups III, IV and V received the test drug 2-4methylphenylimino-3-carboxamide substituted thiophene compound per orally at $10 \mathrm{mg} / \mathrm{kg}, 20 \mathrm{mg} / \mathrm{kg}, 40$ $\mathrm{mg} / \mathrm{kg}$ respectively and all these three groups were considered as test groups. All the grouping details were mentioned below in Table 2 .

Table 2: Classification of mice into the groups in Formalin test.

\begin{tabular}{|c|c|c|}
\hline Group & Drug & Dose \\
\hline $\mathbf{I}$ & Control (10\% tween-80) & $0.5 \mathrm{ml} \mathrm{PO}$ \\
\hline II & Aspirin & $\begin{array}{l}100 \mathrm{mg} / \mathrm{kg} / \mathrm{PO} \\
/ 0.5 \mathrm{ml} 24\end{array}$ \\
\hline III & $\begin{array}{l}\text { 2-4methylphenylimino-3- } \\
\text { carboxamide substituted } \\
\text { thiophene compound }\end{array}$ & $\begin{array}{l}10 \\
\mathrm{mg} / \mathrm{kg} / \mathrm{PO} / 0.5 \\
\mathrm{ml}\end{array}$ \\
\hline IV & $\begin{array}{l}\text { 2-4methylphenylimino-3- } \\
\text { carboxamide substituted } \\
\text { thiophene compound }\end{array}$ & $\begin{array}{l}20 \\
\mathrm{mg} / \mathrm{kg} / \mathrm{PO} / 0.5 \\
\mathrm{ml}\end{array}$ \\
\hline $\mathbf{V}$ & $\begin{array}{l}\text { 2-4methylphenylimino-3- } \\
\text { carboxamide substituted } \\
\text { thiophene compound }\end{array}$ & $\begin{array}{l}40 \\
\mathrm{mg} / \mathrm{kg} / \mathrm{PO} / 0.5 \\
\mathrm{ml}\end{array}$ \\
\hline
\end{tabular}

\section{Procedure}

Drugs were administered orally with the respective drugs. After 1 hour, $0.02 \mathrm{ml}$ of $5 \%$ formalin is injected into the dorsum region of hind paw of mice. Pain response is indicated by the paw licking or biting of the paw. Number of paw lickings 25 was recorded in late phase of 20-30 min. Analgesic response or protection was indicated if both paws were resting on the floor with no obvious favoring of the injected paw.

\section{Evaluation}

Pain inhibition percentage was calculated using the formula: 
$\mathrm{PIP}=[$ No. of Licks (control-treated group) $/$ No. of licks in control] $\times 100$

\section{RESULTS}

\section{Acetic acid induced writhing}

Numbers of writhes were observed for 20 minutes after the intraperitoneal administration of $0.1 \mathrm{ml}$ of $0.6 \%$ acetic acid in each mouse. Following observations were made and presented as mean number of writhes with \pm SD. The control group of mice (10\% tween-80) produced $46.5 \pm 2.33$ writhes. The standard group of mice (aspirin-100 $\mathrm{mg} / \mathrm{kg} / \mathrm{PO}$ ) produced $3.83 \pm 1.16$ writhes and has shown the pain inhibition percentage (PIP) of 91.76 when compared to control group. The test group of mice (test compound$10 \mathrm{mg} / \mathrm{kg} / \mathrm{PO}$ ) produced 26.66 \pm 2.16 writhes and has shown PIP of 42.66 when compared to control group.

Table 3: Mean no. of writhes and pain inhibition percentage produced by control, aspirin (100 mg/kg) and 2chlorothiophene at 10, 20 and $40 \mathrm{mg} / \mathrm{kg}$ in Acetic acid induced writhing test in mice

\begin{tabular}{|lllll} 
S. no. & Group $(\mathbf{n}=\mathbf{6})$ & Mean no. of writhes \pm SD & $\begin{array}{l}\text { Pain inhibition } \\
\text { percentage }(\%)\end{array}$ & P value \\
\hline $\mathbf{1}$ & Control $(10 \%$ tween-80) & $46.5 \pm 2.33$ & - & - \\
\hline $\mathbf{2}$ & Aspirin $(100 \mathrm{mg} / \mathrm{kg} / \mathrm{PO})$ & $3.83 \pm 1.16$ & 91.76 & $<0.0001$ \\
\hline $\mathbf{3}$ & Test compound $(10 \mathrm{mg} / \mathrm{kg} / \mathrm{PO})$ & $26.66 \pm 2.16$ & 42.66 & $<0.0001$ \\
\hline $\mathbf{4}$ & Test compound $(20 \mathrm{mg} / \mathrm{kg} / \mathrm{PO})$ & $18 \pm 2.60$ & 61.29 & $<0.0001$ \\
\hline $\mathbf{5}$ & Test compound $(40 \mathrm{mg} / \mathrm{kg} / \mathrm{PO})$ & $10 \pm 2.60$ & 78.49 & $<0.0001$ \\
\hline
\end{tabular}

Table 4: Mean no. of paw licks and pain inhibition percentage (PIP) produced by control, aspirin (100 mg/kg) and Test compound at 10, 20 and $40 \mathrm{mg} / \mathrm{kg}$ in late phase of formalin induced paw licking in mice

\begin{tabular}{|c|c|c|c|c|}
\hline S. no. & Group $(n=6)$ & $\begin{array}{l}\text { Mean No. of } \\
\text { licks } \pm \text { SD }\end{array}$ & $\begin{array}{l}\text { Pain Inhibition } \\
\text { Percentage }(\%)\end{array}$ & $P$ value \\
\hline 1 & Control (10\% tween-80) & $35.83 \pm 2.78$ & - & - \\
\hline 2 & Aspirin (100 mg/kg/PO) & $5 \pm 1.78$ & 86.04 & $<0.0001$ \\
\hline 3 & Test compound $(10 \mathrm{mg} / \mathrm{kg} / \mathrm{PO})$ & $30.66 \pm 5.85$ & 14.42 & $<0.0001$ \\
\hline 4 & Test compound $(20 \mathrm{mg} / \mathrm{kg} / \mathrm{PO})$ & $25.16 \pm 1.72$ & 29.77 & $<0.0001$ \\
\hline 5 & Test compound (40 mg/kg/PO) & $15 \pm 1.78$ & 58.13 & $<0.0001$ \\
\hline
\end{tabular}

Anova $(\mathrm{P})<0.0001$

The test group of mice (test compound-20 mg/kg/PO) produced $18 \pm 2.60$ writhes and has shown PIP of 61.29 when compared to control group. The test group of mice (test compound $-40 \mathrm{mg} / \mathrm{kg} / \mathrm{PO}$ ) produced $10 \pm 2.60$ writhes and has shown PIP of 78.49 when compared to control group. All the details were explained below in Table 3 and Figure 1.

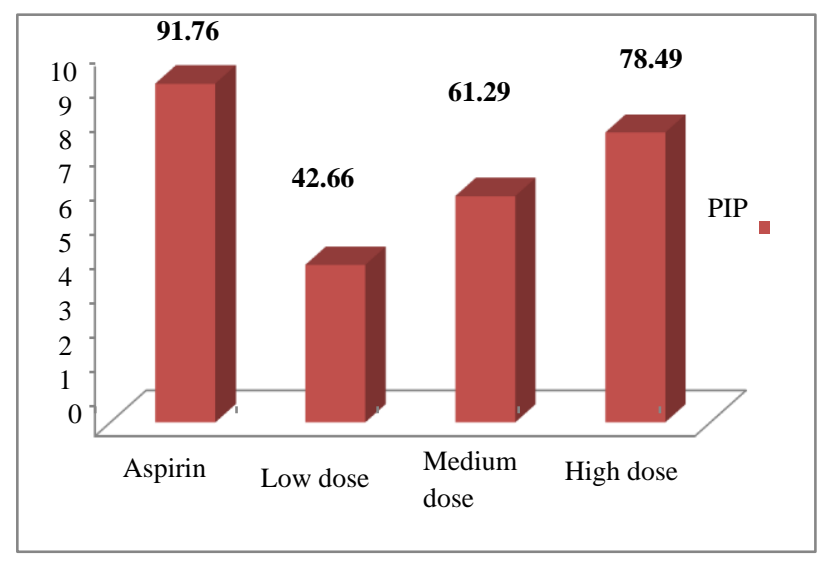

Figure 1: The pain inhibition percentage produced by aspirin $(100 \mathrm{mg} / \mathrm{kg})$ and test compound at 10,20 and $40 \mathrm{mg} / \mathrm{kg}$ in acetic acid induced writhing test in mice.

\section{Formalin induced paw licking in mice}

Number of paw licks

Peripheral analgesic activity of test compound was determined by the late phase. Number of paw lickings were recorded in late phase of 20-30 minutes. Pain inhibition percentage was calculated by comparing the drug treated values to that of control group. Mean number of paw licks and PIP produced in late phase of formalin test shown in Table 4.

\section{Number of paw licks}

Number of paw licks were observed both in in late phase (20-30 min) after the injection of formalin. Following observations were made and presented as mean number of licks with \pm SD. The control group of mice (10\% tween- 80 ) has shown $35.83 \pm 2.78$ licks in late phase. The standard group of mice (Aspirin-100 $\mathrm{mg} / \mathrm{kg} / \mathrm{PO}$ ) has shown $05.00 \pm 1.78$ licks in late phase. The test group of mice (Test compound-10 mg/kg/PO) has shown $30.66 \pm 5.85$ licks in late phase. The test group of mice (Test compound -20 $\mathrm{mg} / \mathrm{kg} / \mathrm{PO}$ ) has shown $25.16 \pm 1.72$ licks in late phase. The test group of mice (test compound- $40 \mathrm{mg} / \mathrm{kg} / \mathrm{PO}$ ) has shown $15 \pm 1.78$ licks in late phase. Pain inhibition 
percentage details were explained below in Table 4, Figure 2.

\section{Statistical analysis}

All the continuous variables in this experiment were expressed as Mean and Standard deviation. Between group analyses was done with one-way ANOVA, followed by Dunnett post hoc test. Within group analyses was done with Repeated measure ANOVA test. All statistical calculations were performed using the software SPSS (statistical package for social service) for windows version 19.0. For statistical significance, two tailed probability $<0.05$ is considered.

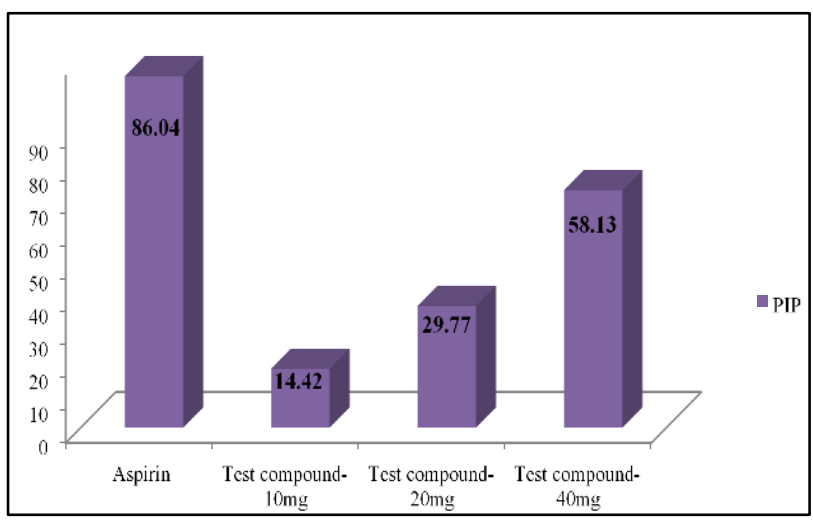

Figure 2: The pain inhibition percentage (PIP) shown by aspirin $(100 \mathrm{mg} / \mathrm{kg})$ and test drug at 10,20 and 40 $\mathrm{mg} / \mathrm{kg}$ in late phase of formalin induced paw licking in mice.

\section{DISCUSSION}

\section{Late phase of formalin induced paw licking in mice}

In late phase, The PIP produced by the Aspirin $(100 \mathrm{mg} / \mathrm{kg})$ is 86.04 whereas PIP values produced by 2-4 methylphenylimino-3-carboxamide substituted thiophene compound are $14.42,29.77,58.13$ at the doses of $10,20 \&$ $40 \mathrm{mg} / \mathrm{kg}$ respectively. This indicates that the maximum PIP is produced by $40 \mathrm{mg} / \mathrm{kg}$ dose of test compound, however the activity is lesser compared to aspirin (100 $\mathrm{mg} / \mathrm{kg}$ ). Viswanatha et al evaluated analgesic activity of Newly synthesized bicyclothieno 1, 2, 3-triazinestest drugs (BTT-1, BTT-2, BTT-3, BTT-4) have showed significant analgesic activity by decreasing the number of lickings in formalin test $(\mathrm{p}<0.01, \mathrm{p}<0.05, \mathrm{p}<0.01, \mathrm{p}<0.01)$, all the test drugs were found to be effective only in late phase of nociception. $^{27}$

\section{Acetic acid induced writhing test in mice}

The PIP produced by the aspirin $(100 \mathrm{mg} / \mathrm{kg})$ is 91.76 whereas PIP values produced by the test compound i.e 2-4 methylphenylimino-3-carboxamide substituted thiophene compound are $42.66,61.29,78.49$ at the doses of $10,20 \&$ $40 \mathrm{mg}$ respectively. This indicates that maximum PIP is produced by $40 \mathrm{mg} / \mathrm{kg}$ dose of test compound, however the activity is lesser compared to Aspirin (100 mg/kg). Molvi et al evaluated the Sets of tetrasubstituted thiophene esters $4 a-4 g, 5 a-5 f$ and $6 a-6 e$ in vivo analgesic activity in acetic acid induced writhing response model at $10 \mathrm{mg} / \mathrm{kg}$ dose exhibited analgesic activity of $56 \%$ inhibition using ibuprofen as standard drug in mice. ${ }^{26}$

The current study infers that 2-4-methylphenylimino-3carboxamide substituted thiophene compound has good peripheral analgesic activity at $40 \mathrm{mg} / \mathrm{kg}$, but lesser than that of Aspirin $(100 \mathrm{mg} / \mathrm{kg})$.

The drug can be claimed for peripheral analgesic activity as the maximum PIP is $>50 \%$ in both Formalin induced paw licking and Acetic acid induced writhing methods. If the study period had been continued, then the complete time course of action for all the drugs could have been recorded. Further investigation can throw light on the minimum effective dose and ceiling doses of all the drugs. This study is a simple screening test for the presence or absence of analgesic activity for 2-4 methylphenylimino-3carboxamide substituted thiophene compound. The purpose of the study is served by demonstrating the analgesic activity in the doses employed. These results cannot be interpolated for human.

\section{CONCLUSION}

From this study, we can conclude that gentamicin is more the study was undertaken for screening of the synthetic compound 2-4-methylphenylimino-3-carboxamide substituted thiophene compound for analgesic activity. It has shown maximum peripheral analgesic activity $(>50 \%)$ at $40 \mathrm{mg} / \mathrm{kg}$ dose in both Formalin induced paw licking and Acetic acid induced writhing methods which cannot be interpreted as having significant peripheral analgesic activity when compared to aspirin $(100 \mathrm{mg} / \mathrm{kg})$. From this study, it can be concluded that the test drug, 2-4 methylphenylimino-3carboxamide substituted thiophene compound has good amount of peripheral analgesic action at $40 \mathrm{mg} / \mathrm{kg}$ dose in mice to a lesser extent. Further studies may be conducted in a greater number of animal species models to evaluate and confirm the findings.

\section{Funding: No funding sources \\ Conflict of interest: None declared}

Ethical approval: The study was approved by the Institutional Ethics Committee

\section{REFERENCES}

1. Taneja A, Della Pasqua O, Danhof M. Challenges in translational drug research in neuropathic and inflammatory pain: the prerequisites for a new paradigm. Eur J Clin Pharmacol. 2017;73:1219-36.

2. Kuchari E, Han S, Karłowicz-Bodalska K, Mis' kiewicz K, Kutycka E. Safety of oral ibuprofen-analysis of data from the spontaneous reporting system in Poland. Acta Pol Pharm. 2014;71(4):687-90. 
3. Clark Michelle A, Finkel Richard, Rey Jose A (2012). Whalen Karen. Narcotic Analgesic. In: Lippincott's Illustrated review of pharmacology. 5 ed. New Delhi: Wolters Kluwer Publication.

4. Miller LR, Cano A. Comorbid chronic pain and depression: who is at risk?. J Pain 2009;10:619-27.

5. Baliki MN, Geha PY, Fields HL, Apkarian AV. Predicting value of pain and analgesia: nucleus accumbens response to noxious stimuli changes in the presence of chronic pain. Neuron 2010;66:149-60.

6. Bromberg-Martin ES, Matsumoto M, Hikosaka O. Dopamine in motivational control: rewarding, aversive, and alerting. Neuron. 2010;68.

7. Chaudhury D, Walsh JJ, Friedman AK, Juarez B, Ku SM, Koo JW, et al. Rapid regulation of depressionrelated behaviours by control of midbrain dopamine neurons. Nature. 2013;493:532-6.

8. Gupta AK, Parasar D, Sagar A, Choudhary V, Chopra BS, Garg R, et al. Analgesic and Anti-Inflammatory Properties of Gelsolin in Acetic Acid Induced Writhing, Tail Immersion and Carrageenan Induced Paw Edema in Mice. PLoS ONE. 2015;10(8):e0135558.

9. Wagnat WW, Omar MEAS, Gamal A. E. Screening for antidepressant, sedative and analgesic activities of novel fused thiophene derivatives; Acta Macuet. 2008;58:1-14.

10. Naomi I, Matthew D. Why it hurts to be left out - The neurocognitive overlap between physical and social pain; Williams_RT424X_C07. 2005;109-27.

11. Merskey H, Bogduk N. Classification of Chronic Pain. International Association for the Study of Pain: 2nd ed. Seattle: 1994;3-4.

12. Clifford JW. What is this thing called pain? J Clinic Investigat. 2010;120(11): 3742-4

13. Jennifer NS, Tricia K, Janet Y, Navreet G, Bonnie S. Systematic review of the psychometric properties, interpretability and feasibility of self-report pain intensity measures for use in clinical trials in children and adolescents; Pain. 2006;125(1):143-57.

14. Varni JW, Thompson KL, Hanson V. The Varni/Thompson Pediatric Pain Questionnaire. I. Chronic musculoskeletal pain in juvenile rheumatoid arthritis; Pain. 1987;28(1):27-38.

15. Common Laboratory Animals. In: Ghosh MN. Fundamentals of Experimental Pharmacology. 6th Ed. Kolkata: Ghosh SK and Others; 2015:1-13

16. Dnyaneshwar JT, Maruti GW, Rajendra SB, Ravindra YP; Antinoceptive activity of Ricinus communis L. leaves. As Pacif J Tropic Biomedic. 2011:139.

17. Singh S, Majumdar DK. Analgesic activity of Ocimum sanctum and its possible mechanism of action. Int J Pharmacogn. 1995;33(3):188-92.
18. Dannerman PJ. Monitoring of analgesia in anesthesia and analgesia inlaboratory animals. In: Kohn DK, Sally K, Wixson B, White WJ, John G, editors. Ch. 6. USA: Academic Press; 1977;83-99.

19. Vendruscolo A. Anti-inflammatory and antinociceptive activities of Zingiber officinale Roscoe essential oil in experimental animal models; Indian J Pharmacol.2006 Feb ; Vol.38(1): 58-9. Bhutia YD, Vijayaraghavan R, Pathak U. Analgesic and antiinflammatory activity of amifostine, DRDE-07, and their analogs, in mice. Ind $J$ Pharmacol. 2010;42(1):17.

20. Shanmugasundaram P, Venkataraman S. Antinociceptive activity of Hygrophila auriculata (Schum) Heine. Afric J Tradit Complement Alternat Medic. 2006;2(1):62-9.

21. Central Analgesic Activity In: Vogel HG, Vogel WH, editors. Drug discovery and evaluation: pharmacological assays. Springer Science \& Business Media. 3rd Ed. Newyork: Springer-Verlag Berlin Heidelberg; 2008:984-1030.

22. Hemamalini K, Om Prasad Naik K, Ashok P; Antiinflammatory and analgesic effect of methanolic extract of Anogeissus acuminate leaf; Int J Pharm Biomed Res 2010;1(3):98-101.

23. Hunskaar S, Hole $\mathrm{K}$. The formalin test in mice: dissociation between inflammatory and noninflammatory pain. Pain. 1987;30(1):103-14

24. Hemamalini K, Om Prasad Naik K, Ashok P; Antiinflammatory and analgesic effect of methanolic extract of Anogeissus acuminate leaf; Int J Pharm Biomed Res 2010;1(3):98-101.

25. Hunskaar S, Hole $\mathrm{K}$. The formalin test in mice: dissociation between inflammatory and noninflammatory pain. Pain. 1987;30(1):103-14.

26. Molvi KI, Mansuri M, Sudarsanam V, Patel MM, Andrabi SM, Haque N. Synthesis, anti-inflammatory, analgesic and antioxidant activities of some tetrasubstituted thiophenes. J Enzyme Inhib Med Chem. 2008;23(6):829-38

27. Viswanatha GL, Akinapally N, Shylaja H, Nandakumar K, Srinath R, Janardhanan S.Analgesic, Anti-Inflammatory and Antiarthritic Activity of Newly Synthesized Bicyclothieno 1, 2, 3 - Triazines. Maced J Med Sci. 2011;4(2):131-8.

Cite this article as: Ganugapeta N, Reddythala SSK. Screening of novel 2-4methylphenylimino-3 carboxamide substituted thiophene compound for peripheral analgesic activity. Int J Basic Clin Pharmacol 2021;10:281-6. 